\title{
The Naturalization of Gender Segregation in a Danish Bank'
}

I Sidsel Lond Grosen

Assistant Professor, Centre for Working Environment and Working Life, Roskilde University, Denmark

I Helle Holt

Senior Researcher, The Danish National Institute of Social Research, Denmark

\section{Henrik Lambrecht Lund}

Associate Professor, Centre for Working Environment and Working Life, Roskilde University, Denmark

\begin{abstract}
Through a qualitative interview analysis of a document handling department in a Danish bank, this article seeks to illuminate central aspects of how some jobs come to be seen as naturally female. Taking gendered organizational theory and Joan Acker's concept of an ideal employee as our point of departure, we ask whether women are seen as the ideal employees in this femaledominated job function or as a residual to men as the actual ideal employees. The numerical female dominance in the document handling department is articulated as a matter of competencies, job content, and family obligations - for example, by framing women as good at multitasking, as enjoying routine work, and as primary caregivers. The article argues that this construction both draws on and alters historically formed stereotypes in ways that reinforce the gender segregation of the organization and make it hard to change.
\end{abstract}

\section{KEYWORDS}

Gender segregation / gendered organization / ideal employee / naturalization / competencies / bank / Denmark.

\section{Introduction}

ome with us, take a look through the glass door at the document handling department in the bank. Through it you see an open office landscape predominantly inhabited by women, all working in front of their computer screens. Of the department's approximately 70 staff, 64 are women. We are looking at a live performance of the gender segregation of the financial sector.

Assistant Professor Sidsel Lond Grosen, Centre for Working Environment and Working Life, Department of Environmental, Social and Spatial Change, Roskilde University, P.O. Box 260, DK - 4000 Roskilde, Denmark, E-mail: sgrosen@ruc.dk, Tel.: +45 467432 31, www.ruc.dk 
The gender segregation of this department is obviously formed by historical processes within banking and administrative work in general (Acker, 1994/2006; Grosen, Holt, Hvid \& Lund, 2010; Holt, Hvid, Grosen \& Lund, 2009). But being established as late as 2001, the overwhelming numerical female dominance in the document handling department raises questions about the reasons for gender segregation anew. Many of the factors explaining gender segregation in banking and administrative work no longer make sense - historically speaking. Despite this, no one in our case study of the document handling department in a medium-sized bank seems to question how a reorganization of work, around the year 2001, in Denmark, can end up creating or reinforcing gender segregation on such a large scale. Neither do very many others who work in the sector seem to question it, though the same kind of reorganization with the same consequences of creating or reinforcing gender segregation took place at that time (Holt et al., 2009). Why is it that this gender segregation of labor is presented as almost inherently natural even today? How does this naturalization take place and, more particularly, how is the female dominance in the document handling department articulated as natural within the workplace?

We understand the naturalization of the gender segregation as the interrelated processes which take place historically, socially, and in the individual workplace. The effect of these processes is that the gender segregation of labor is seldom questioned, that, on the contrary, it is often perceived as a natural consequence of gender as such.

\section{Perspectives on the naturalization of the gender segregation}

The theoretical field concerning the gender segregation of labor has long been characterized by a distancing from the naturalization of 'what gender is.' Accordingly, we will establish an analytical framework that can be used to analyze how local constructions of gender are of significance to the construction of gendered job types and thus the gender segregation of labor.

\section{The gendered organization}

We will do this by using gendered organizational theory, which highlights how the construction of gendered job types takes place. We take this point of departure because of the theory's focus on workplace processes, interactions, expectations, and everyday working practices. Our focus will not be on what gender is, but on how gender and work are constructed, and in particular on how they are naturalized in relation to each other in connection with the gender segregation of labor.

Organizational structures have been an important area for investigations into gender segregation. Moss Kanter (1977) first introduced the term 'structure of opportunities' to explain why women always got the low status positions and underpaid jobs. She argued that changing workplace structures (such as formal working hours) would eliminate workplace gender segregation. However, research has persistently shown that this is not the case (Acker, 1990, 2006a; Due Billing, 2005; Holt \& Lewis, 2011; Swanberg, 2004). The purely structural angle overlooks the interaction between organizational structures and actual men and women, and subsequent assumptions and normative working practices which are 
an important part of gender constructions (Acker, 1990, 2006a; Due Billing, 2005; Martin, 2003, 2006).

Acker (1990) argues that the workplace is one arena in which cultural images of gender are invented and reproduced. Thus, knowledge of cultural production is important for understanding gender construction. Organizations consist of relations between people and can never be gender-neutral - they will always be gendered. To say that an organization is gendered means "... that advantage and disadvantage, exploitation and control, action and emotion, meaning and identity are patterned through and in terms of a distinction between male and female" (Acker, 1990, p. 146).

\section{The ideal employee}

Organizational structures tend to be built on a cultural picture of the ideal worker as a man, or one who works in ways typical of men (Acker, 1990; Højgaard, 1993). This affects how commitment is defined and competences are valued (Grugulis \& Vincent, 2009; Rees \& Garnsey, 2003; Swanberg, 2004). Commitment is widely constructed in terms of work primacy, such that the time spent at work is expected to be unlimited, and the demands of family, community, and personal life are secondary. Assumptions about commitment and competence are linked with the idealized images of men and masculinity in ways that make it difficult for women's achievements to be recognized (Bailyn, 2006; Grugulis \& Vincent, 2009; Rees \& Garnsey, 2003). Therefore, the deconstruction of structures and cultural norms at work and their underlying assumptions is a first step in analyzing a workplace using a gender lens.

Acker performs such an analysis and creates the concept of the 'ideal employee' (1990). She shows how seemingly gender-neutral job descriptions, the complexity and working conditions of jobs, and the effort and skills required to do any job, in reality, are anything but gender-neutral (ibid. 1990), an analysis which is also supported by newer studies (see, e.g., Bloksgaard, 2008; Rees \& Garnsey, 2003). Acker argues that the very notion that you can make an abstract job description which is separate from the person who is to fill the job contains an ideal about the worker as someone who only exists in relation to the job itself (Acker, 1990). Such a notion is precisely not gender-neutral, which Lis Højgaard explains as follows:

"The worker that comes closest to this ideal is the male worker whose life is centered on full-time work. 'Job' as a concept therefore implicitly becomes a gender-based concept. The female worker, who is presumed to have legitimate commitments in addition to the job, does not fit into the abstract job category."2 (Højgaard, 1993)

Thus it is argued that the abstract notion of the ideal employee means that the ideal employee will be male because males are expected to have fewer care obligations.

According to this line of argumentation, the 'ideal employee' is per se male. Nevertheless, a lot of jobs are in numerical terms female dominated, for instance in the administrative sector. The question is whether women are seen as the ideal employee in these job functions or are seen as a residual to the ideal employee. There are strong arguments for the last statement. Job functions in female-dominated areas are characterized by low status, low pay, part-time work, dead-end jobs, and poor learning opportunities 
(Holt \& Lewis, 2011; Smithson et al., 2004). In contrast, male-dominated jobs are often and especially in comparison with female-dominated jobs described as well-paid fulltime jobs with good career and learning opportunities (Holt \& Lewis, 2011). Although it is possible to find jobs where women dominate numerically, the reason seems to be men's deselection more than women's choices.

Nevertheless, some job functions are constructed around perceptions of women's competences and women's needs. Some competences are seen as particularly related to women such as a natural ability for caregiving, empathic behavior, accuracy, multitasking, and the like (Britton, 1997; Rees \& Garnsey, 2003). Furthermore, female-dominated workplaces are often characterized by an expectation of women's needs as related to being primary caregivers in their respective families; this means that these workplaces often prioritize, for instance, family friendliness as, for example, part-time work, acceptance of leaves, flexi time, etc. (Holt \& Lewis, 2011; Perrons, 2003). Such expectations to women often build on gender stereotypes. Yet, as studies have shown, they also reflect a demand for family friendliness from actual women (Bloksgaard, 2008; Holt \& Lewis, 2011; Smithson, et al., 2004). Likewise, some competences are often handled by the workplace as being particularly female, while they are also reflected in actual women's characterization of women. Thus, female-dominated workplaces might reflect both deselection from the universal 'ideal employees' in the image of male employees and an active choice from women as well as from workplaces, structuring their work around stereotype images of women and their competences and needs. In such cases, the numerical female domination of some job functions must be understood as both a matter of residual and ideal labor, where women and their competences are seen as ideal for some job functions. In the following empirical analysis, we for instance often see that notions about a relationship between gender and competences are linked to female-dominated job types. In this way, the actual ideal employee could be a woman, even though skill requirements etc. are described in gender-neutral language.

Acker's aim is to discuss and describe how organizational structures are built on a cultural picture of the ideal worker as a man. Therefore, she does not discuss the above questions in her original work on 'the ideal employee.' This omission does not exclude, however, that organizational structures create residual jobs that are at the same time built on a cultural image of women as the ideal employee. In her later works, she returns to the subject matter, where she comments on situations as the ones we are addressing without discussing them theoretically:

\section{Highly experienced workers doing complicated knowledge work for low pay in positions classified as 'clerical' or 'allexpeditor' or 'unpromoted' are a valuable resource for employ- ers wishing to save money by transferring responsibilities downward in organizations. (Acker, 2006b, p. 212)}

We will see the construction of the ideal employee as a condensation of the organization's discursive construction of a gendered job type more generally. The ideal employee is thus taken to be an underlying ideal, which employees in the organization can orientate themselves toward and compare themselves to as an abstract role model (Eriksson-Zetterquist, 2008). As such, it can be used as an analytical construct to explicate how naturalized relations between gender and skills are reproduced within an organization, following a similar rationale as other studies of gender stereotypes in organizations: 
[I]nterpretations of what it means to be 'successful' in a corporate culture, and the stories reflecting these ideals in organizational talk, can be crucial means to an understanding of the phenomenon.(...) These stereotypes will restrict the individual choices within the organizational boundaries. (Aaltio-Marjosola, 1994)

Recent research (Bailyn, 2006; Martin, 2003, 2006) highlights the importance of examining everyday working practices in specific workplace contexts rather than attempting to generalize about gendered practices. In this article, we draw on gendered organization theory in examining one specific workplace. We explore the ways in which organizational structures and processes and the cultural images of gender influence gender segregation. We will especially look at

- how organizational development and structures create and reinforce gender segregation;

- how competences are articulated as being valued differently according to what gender is numerically dominant at the workplace;

- how the document handling department and the work are constructed as low status;

- how family obligations are seen as the explanation for female dominance, in terms of number, at the document handling department;

- how an 'ideal employee' is constructed in relation to the bank's document handling department.

\section{Data and method}

The research reported here explores the contemporary gender segregation of labor through an examination of how gender segregation comes to appear as a natural consequence of gender and/or the job content. This naturalization is explored through (1) a short examination of the organizational development leading up to the centralization of certain private customer functions in the establishment of the document handling department; (2) an interview analysis focusing on how female dominance in the document handling department is articulated as being natural within the workplace.

The document handling department has become the center of this study by a roundabout way: While doing interviews at the document handling department as part of a research project with a slightly different focus (Grosen et al., 2010; Holt et al., 2009), it struck us as being remarkable how such a relatively large organizational restructuring in a country which generally sees itself as having achieved a high degree of gender equality can end up being so extremely dominated by one gender. Paradoxically, at the same time, this appeared to be not reflected upon in the organizational process and very well articulated as naturally related to gender. That became the starting point for this article.

The case study on which our analysis is based consists of interviews with male and female employees in a medium-sized Danish bank, all conducted in 2007. First and foremost, we interviewed employees in the bank's document handling department. Here we undertook individual semi-structured, qualitative interviews with two of the department's three managers (one woman, one man), the trade union representative (a woman), and six document handling employees of different ages and experience (all women). The interviews were focused on their explanations as to why almost only women are 
employed in the document handling department, explanations that reflect the arguments for the trend in administrative work and the changing male/female dominance.

In addition to the interviews in the document handling department, we also interviewed a number of advisors/salespersons from the bank's branches enabling us to better understand the organization and the employees' career opportunities, as most of the employees in the bank's document handling department come from the branches. It gives us the opportunity to juxtapose statements about the different job positions in the bank and thereby add nuances or question them.

The analysis of the interviews is focused around two related aspects: (1) the articulation of the relation between gender and the work, and (2) how this reflects a construction of an 'ideal employee.'

The articulation of the relation between gender and work in the interviews has been analyzed by concentrating on the reproduction and displacement of meaning. We have analyzed how statements are related to other statements in hierarchical relations, differentiating themselves from or marking themselves as equivalent to other statements. For example, some skills are articulated as female by equating them with other already feminized skills and by differentiating them from masculinized skills; the same skills can be articulated as especially valuable in the context of document handling work, while other skills can be articulated as more valued in the bank in general. This contributes to an understanding of the creation of some of the discursive constructions ${ }^{3}$ available when gender is associated with document handling in the bank which is subject to our analysis.

The de- and reconstruction of the workplace's ideal employee is made by focusing on three aspects of the discursive constructions in the interviews: (1) the ascription of value to certain skills and competencies in relation to the work in the document handling department; (2) arguments about the division of work into separate functions; and (3) statements about the rationale behind the organization of the work. The image of the ideal worker is then used to discuss how gender segregation is reproduced within the organization.

\section{The Historical Context of Administrative Work}

The historical basis for the gender segregation of the financial sector, and document handling functions in particular, must be seen in relation to developments in administrative work in general. The trend in administrative work over the past 100 years both represents big changes and marked inertia in the gender segregation of labor. Until around the year 1900, administrative work in Denmark was almost exclusively performed by men. Just 20 years later, $56 \%$ of the people working in administrative work were women (Juul, 2008). Administrative work simply switched gender. Today, around $70 \%$ of employees in administrative job functions in Denmark are women (Holt et al., 2009).

Three main explanations seem to have dominated the discourse of administrative work as being female work from the beginning up until around the middle of the 20th century (Boyer, 2004; Juul, 2008):

- office work was respectable work for middle-class (mostly unmarried) women;

- women were generally cheaper labor since only a few women achieved any particular seniority, or had obligations to provide for others than themselves, as many stopped working after they got married or had children; 
- women were seen as being better suited than men to do routine tasks especially in office work.

These explanations represent a process of naturalization by which the work was linked to the female gender. Women's share of routine administrative work was thus presented as something inherently natural:

"[...] women are superb office clerks and are especially suitable as shorthand typists. They are often less capable at acting on their own initiative, however, on the other hand, they provide better and more solid mechanical work than men, their tidiness and punctiliousness are reliable, and their persistence considerably greater, especially since, due to their nature, they tireless from rule-bound work." (The male principal of a Copenhagen commercial school in 1916, quoted in Juul, 2008)

Although the principal was a man, it is not the impression from other studies that the above citation is a particular male gaze at women's competences. On the contrary, the description seems to fit a more general perception of women's competences at that time - including women's own understanding (Geertsen, 1990). The cultural image of women was of course based on a high level of gender segregation at the labor market and a strong division between private and public spheres. Despite the different conditions, some of the same descriptions of women's competences appear in our contemporary case study, as we will return to.

The role of the history of administrative work for understanding gender segregation in a banking department of today is ambiguous: Today, gender segregation can no longer be explained by the notion that certain jobs are particularly respectable for women or that women withdraw from the labor market when they marry. In Denmark, women stay in the labor market throughout their working life irrespective of their marital status (Deding, 2010; Deding \& Laustsen, 2008). Moreover, when it comes to newly established jobs, gender segregation cannot be explained by a long tradition of associating certain types of jobs with the female gender. Thus, several of the above-described factors have changed today. Nonetheless, some of the articulation of work 'explaining' gender segregation is apparently still valid. Therefore, the context of the history of administrative work in general contributes an understanding of the creation of some of the discursive constructions available when gender is associated with document handling in the bank which is the subject of our analysis.

\section{The Study of Document Handling in the Financial Sector}

Document handling in the financial sector is an interesting example of a newly established and extremely female-dominated job function. In the past 10 years, document handling has emerged as a separate job function in banks. This has come about in connection with a division of work into, on the one hand, document handling and, on the other hand, advice/sale of, e.g., a loan. Employees in the document handling department are mostly recruited from positions as advisers/salespersons (Holt et al., 2009). This newly established gender segregation of labor can therefore not be explained by educational background, a common explanation for gender segregation of labor (cf. ibid.; 
Danish Ministry of Employment, 2002), since document handling employees and advisers/salespersons typically share the same educational background.

In recent years, not the least, work linked to loan processing has been subject to large changes. There has been a division between sale and customer relations on the one hand and the so-called back-office functions (the paper work) on the other hand - a division between the salesperson who enters into loan agreements with customers and the support staff who handle the documents associated with the loan agreement (Holt et al., 2009; Smistrup, 2003). At the same time, the gender segregation of labor has increased. Approximately $60 \%$ of staff in Danish banks is women. The sales function is filled by both men and women, however, with a slight overweight of women among those dealing with private customers and a marked overweight of men among those dealing with corporate customers (Financial Services' Union, 2006). However, the proportion of women support staff is almost 100\% (Financial Services' Union, 2006), and women are extremely underrepresented at the managerial level (Ellehave \& Søndergaard, 2006). Recent years' adjustments in loan processing therefore add to gender segregation in the sector, as it is also seen in other large organizational changes as, for example, mergers (Tienari, 2000).

In the bank we studied, the division between sales and the back-office functions led to the decision to regionalize, so that back-office functions or document handling became concentrated regionally and later - in 2000 and 2001 - the bank went all the way and moved practically all document handling to its head office. With very few exceptions, the back-office functions are staffed exclusively by women. Both men and women were given the choice of swapping from the sales function to document handling, but only women chose the back-office function. Since then the function changed name, the back-office function became document handling and moved to a central department.

One of the department's three middle managers comments on the reorganization process, which resulted in the marked gender segregation:

"If I am to offer an explanation for it (...) I think it has something to do with prestige and lack of prestige. (...) There is not a lot of prestige associated with being a producer of documents, there really isn't. And this is so, whether we like it or not, there just isn't prestige in it. And therefore I think that when people had to make a choice (...) it was all men who hung on to the job as adviser. Despite the fact that it wasn't necessarily the job they were best at, nor basically what they wanted the most (...) There were many girls who chose to say: "I'm good at that and comfortable with that. So this is what I want, and so this is what I'll do"."' (Peter, male manager)

The manager frames the numerical female domination of the document handling department as a mix of status and individual choice. On the one hand, what one 'is best at' is presented as a factor that ought to determine the individual choice of job function. On the other, status is articulated as framing the individual choice in explicitly gendered ways, resulting in gender segregation, as status is presented as being of greater importance to men than what type of work they do best while women are presented as answering to their professional expertise.

Our material does not offer the opportunity to explore the organizational process leading up to divisions of back-office functions from sale and customer relations or the centralization of the document handling functions in much depth. However, our interviews 
point to a repeated framing of sales as well as document handling functions in terms of stereotype gender characteristics. The interviews also left the impression that the bank excelled in making its' employees choose their career path in accordance with the bank's wishes and image of the employee.

Of the department's approximately 70 staff members, 6 are men, 3 of these are managers, 2 are temporary staff and just 1 is permanently employed in a document handling function and is also the department's IT super user. The majority of the employees in the document handling department were trained in the bank or in other types of financial institutes, and a few have a clerical background. Many of the employees with banking training have previously worked as salespersons and are described by one of the managers as sometimes more knowledgeable than the salespersons they assist.

The gradual centralization of the document handling in the bank empirically raises the question of whether or not the female domination of the document handling department is to be understood as a function filled with residual workers or as the construction of an alternative, female, ideal worker, though she might be working on relatively poor terms.

\section{Low status and female competences}

In the interviews, the women in particular talked about gender in relation to daily work routines when asked why the document handling department is almost exclusively staffed by women. It is important to emphasize that the answers to this and similar questions should not be interpreted as explanations as to why this is the case. Rather, these answers should be read as constructions that give meaning to the way things are. However, they can also contribute to maintaining things as they are or, potentially, create change.

Let us look at an example where we ask Line why no men want to move to the document handling department:

"I think it probably has something to do with there being no status in working here, and that we are the worst paid, and it's like...it's just 'the ones from the document handling department'. Yes, I think it probably means a lot. (...) I think it has to do with the way men and women are, and I can get sort of all nervous if a man was to do it [the document handling], if it wasn't someone that I knew well, because everyone knows that men can't keep several balls in the air at once, and all that. Yes, it means a lot that you are able to stop and think "what will happen if you do this", and men don't think like that, they do it and then..." (Line, female document handler)

It is curious as to what happens in relation to the ascription of status in the relationship between document handling and gender. First, the document handling department is presented as being associated with a low status relative to other job functions in the bank. This is linked to gender by being articulated as an explanation of why, apparently, men do not seek employment in the document handling department; the argument seems to be that men do not seek employment in a low-status department, whereas women do. In the very next moment, the hierarchy is turned around in relation to gender through a genderification of the work as such: Things are presented as being a matter of "the way 
men and women are," and, against this background, men are not able to fill a document handling function "because everyone knows that men can't keep several balls in the air at once," and because they do not stop to think about the consequences of what they do. Knowing a man well, however, can make it possible to trust his skills and sense of responsibility. But generally, men are attributed low and women high competences in relation to document handling.

As in the 1916 statement made by the principal of a Copenhagen commercial school, the 2007 statement made by Line from the document handling department gender is constructed as being inherently linked to certain competences. According to Line, these competences can correspond more or less completely with the competences which are also presented as being required to carry out document handling. This gives an image of the ideal employee. In the document handling department, women and men are constructed as possessing different, almost complementary competences related to their gender. Men are unable to multitask and therefore there are no men in the document handling department (implying that since there are women in the document handling department, women can multitask), and men are also unable to understand the consequences of what they do (implying that since there are women in the document handling department, women understand the consequences of what they do). However, men can prove their suitability for document handling, so the construction opens up the possibility that men could possess the desired competences.

The way the coupling of gender with status is articulated within the document handling department appears to be in conflict with the way it is articulated outside the department. The employees at the department seem to accommodate this by applying a double perspective, enabling them to view their work simultaneously from within and from the outside. The double perspective includes for some of the female employees elements of frustration - or anger - addressing a perceived disproportion between status and competences.

The match between, on the one hand, the job content of the document handling function and, on the other hand, the competences presented as female is articulated several times, and the coupling of the nature of the work with gender is quite explicit:

"I think that - in the job we have to do here - women are more meticulous, and what we do here requires accuracy." (Anna, female document handler)

Women are equated with being "more meticulous," which is presented as the quality required for the job. At the same time, this is highlighted as differing from the competences men possess. Accuracy, a focus on details, and the ability to keep several balls in the air are pointed to repeatedly in the interviews as important aspects of document handling.

Thus, there are both similarities and differences relative to the 1916 quotation. The resemblance consists of a focus on "accuracy" and similar competencies, while the difference consists of the emphasis on understanding the full picture. While "accuracy" in the 1916 quotation is coupled to a natural ability to endure monotonous work, in the interviews from the document handling department, accuracy is coupled to an actual competence in the form of understanding the full picture. In the document handling department, women are not only being written into the work; men are also to a far greater extent being written out. 
However, the notions that women are willing to endure monotonous work and that they are competent are both at stake today. This is illustrated in the trade union representative's answer to the question of whether the management realizes that the document handling department is a female-dominated workplace:

\begin{abstract}
“(...) I don't think many men want to work in the way that we do (...). But I think that of course they [the managers] are aware that we are women, because as [an in-house consultant] said in an interview that I read, it is the women that are able to multi-task; you have to keep several balls in the air at once, don't you. And that is what we are good at here, we understand the full picture and try to get some structure into things." (Eva, female trade union representative, document handling employee)
\end{abstract}

Just as Line, Eva presents document handling as something men are not interested in. Then, she equates women with being able to keep several balls in the air at once, which in turn is identified with the type of work that is carried out in the department. At the same time, this is presented as being the management's perspective on things. Again the double perspective from within and from the outside is applied: Women are attributed high competences in relation to the work in the document handling department, and women are made out to be ideal employees due to their gender, while document handling is attributed low status compared with other work. Eva does, however, express a wish, from the document handling department's side, to break with the extreme gender segregation of labor and hire more men, as she says:

"I don't think we have had any male applicants. I simply don't think there has been any. Because, as I say, in this department just being male is a qualification. Because it somehow contributes to softening the environment if you are a more mixed group of people." (Eva, female trade union representative, document handling employee)

In this way, again, she articulates gender as relevant in itself. When it comes to the male gender, however, men are presented as relevant not in terms of the way they perform the work, but because they contribute to creating a better atmosphere. Not only are the qualifications required to perform the work characterized as particularly female, as we have seen in the previous quotations, male gender is decoupled from the qualifications needed. Despite the accentuation of a wish for more men in the department, the remark still reflects and contributes to the one-sided coupling of gender and work through competences and status. Eva's remark also points to the question of whether the job handling function is female dominated due to it being a residual function or due to the idealization of necessary competence as female. The repeated articulation of gender, work, competences, and status indicates that it might not be one or the other.

However, if we look at the gendered practices in the document handling department and compare them with other jobs, it becomes evident that the coupling of the female gender to document handling is not due to inevitable requirements inherent in the work. In different jobs, different linkages between similar job requirements and gender are often made (also see Martin, 2003). For example, being able to multitask (which in the interviews was presented primarily as a female competence required for document handling in the bank) is a requirement in the male-dominated pilot profession, only here it is described as an ability to carry out many duties simultaneously. Even in the 
local branches of the same bank, the ability to multitask is articulated as an important competence for sales work but here it is linked to male employees. A male employee in a branch talks about his job:

"You have to be good at keeping many balls in the air, because something always comes up. You can't just say: Now I concentrate on this until it is done and don't do anything else simultaneously." ${ }^{\prime 10}$ (Jakob, male salesperson)

It is remarkable how these are almost the same words women at the document handling department use to explain why there are almost only women employed at the document handling department. The example shows that the same competence can be valued differently depending on how the competence is linked to gender. When the competence to multitask is linked to women, it gives the competence a touch of low status, whereas the opposite is the case when the competence is linked to men.

\section{Summary of low status and female competences}

When asking the women in the document handling department why the department is numerically dominated by women, the answer is that no or low status is linked to women and the work at the department has low status. The women also claim that men would be unable to carry out the work tasks in the department because they are not able to multitask and they cannot do the work accurately. Women, on the other hand, can. This is presented as just the way women and men are. Thereby, the competences framed as necessary to maintain the work in the document handling department are constructed as being universal female competences - they become naturalized. The female document handlers apply a double perspective on their job function - from within and from the outside - whereby their work simultaneously appears as a residual function, that men do not want to possess, and a function, where women are the ideal employees. The explanations for the numerical female domination of the department cannot be taken to be universal, though. The explanations are specifically linked to the work tasks in the document handling department and serve as a justification of why the department is a female-dominated workplace with low status and low wages - a justification which must be expected to have consequences for future engagements and the organization of the work. The explanations must also be seen as gendered in their coupling of the specific competencies and low status, as the same competencies can be found to lead to a high status in male-dominated jobs.

\section{Low status and work-life balance}

The linkage between status, different positions in the bank, and gender is apparently the object of frustration for many of the employees in document handling functions. They talk about poorer wages as well as low priority in the organization. Line, who until very recently was employed in another bank, challenges the naturalization of coupling of low status with document handling: 
"It is the poorest paid job and so on. (...) I am not used to this structure, that you can say that this is a poorly paid job; it wasn't where I worked before. So in this respect, it is sort of: 'weeell, it's just a flock of cackling hens, isn't it'. Even though one could say it's us the advisers call when they need to know how things work, because they don't know that themselves do they." 11 (Line, female document handling employee)

That document handling is low status or, at least, low-paid work is presented as something special for this bank, compared with her former workplace, and this challenges the naturalness of the distribution of status. ${ }^{12}$ However, she maintains the linkage between low status and women. Furthermore, with the description of her experience of how the document handling department is seen as "a cackling flock of hens," an expression negatively associated with femininity, she implies that the female numerical dominance could be seen as part of the reason for the low status associated with the work.

On the other hand, a member of the management, as quoted in the description of document handling in the financial sector, articulates the status, or the lack of status, which from an outside perspective is linked to the document handling function, as the reason for the female numerical dominance in the department. Just as Line and Eva, he presents the act of choosing based on the status associated with the job as a gendered action. In contrast to the previous quotations, here the content of the job is not articulated as being dependent on gender; however, status is presented as being of greater importance to men than the type of job they do best. This contributes to upholding the logic of the female dominance in the document handling department.

The same manager, Peter, also brings the relationship between work and family into the discussion. At this point in the interview, we still talked about the historical development in the bank, where the document handling department was first separated from the sales function in the individual branches, then combined into regional centers, and, finally, centralized.

"And then there was another element to it, which is also important, because, you see, back then, and of course today as well, it is the women who most often have problems with children and picking up and so on. And we had, and still have, the opportunity to offer very flexible working hours. The employees in the document handling department can more or less decide their own working hours." ${ }^{13}$ (Peter, male manager)

Women are presented as those who, compared with men, most often have "problems with children." Thus, women are articulated as being the primary caregivers for children, which is equated to a greater need for flexitime. This is equated to the working conditions in the document handling department, which again underpins the predominance of women as being meaningful. On the one hand, it is presented as something which the management of the bank has little power to regulate, as they do not decide who are to be the primary caregivers in the families (but it is assumed to be the women). On the other, the bank has chosen to offer flexible working hours in this particular part of the bank to attract female employees. It is presented as a trade-off between status (and related to this, wage) and flexible working hours, and female employees are the ones who are expected to buy into these conditions, and some obviously do. 
This coupling of work, family, and gender is also found in the interviews with regular document handling employees:

"Despite the way our society is organized, most often it's the women who look after the children (...) I can come to work for example at 7.30 am, and this means I can leave early and go home and be with my children. I couldn't do that if I worked in one of the branches, which don't open until $10 \mathrm{am}$. My husband is self-employed, but before he worked in a bank. Typically, if you work in one of the branches, you start later in the morning and then you also come home later in the afternoon, but it won't work if the other parent also works late hours." ${ }^{14}$ (Agnete, female document handling employee)

Here, for Agnete, gender becomes relevant in her work due to a gendered segregation of labor in the family. This segregation of labor is naturalized and generalized through a reference to "our society," and because "most often" it is the women who take care of the children. In this construction, flexible working hours become more relevant for women than for men when the daily responsibilities relating to taking care of the children have to be met.

However, how flexible working hours actually are in the document handling department is open to question. The interviewees talked about long periods with massive overtime work and unpredicted fluctuations in the work load that can lead to unpredicted overtime. It seems to be clear to both managers and employees that these periods of extensive overtime have very unpleasant implications for employees' work-life balance. However, this concern is not extended to a general consideration of whether the work is really that family friendly, when it seems to be a general condition that employees complete their assignments "also when things are very busy" (Agnete, female document handling employee). As things have been very busy for a very long period of time, family friendliness comes to appear more like storytelling than a reflection of the actual working conditions in the department.

Women at the department articulate the work at the branches as not family friendly because of the working hours and a lack of flexibility toward family needs. When we ask men in the branches about the possibility for flexible working hours they tell us a different story:

"I can organize my working day as I wish. Of course the boss comes up with something concerning some meetings from time to time but apart from that I handle it myself. But I have to do what I've promised the costumers to do." ${ }^{15}$ (Jesper, male salesperson)

"I decide my own working hours, responsibly of course. The work is flexible and can easily be combined with having small children." 16 (Allan, male salesperson)

Despite the male salespersons' experiences of flexibility of the work in the branches, this work is not generally framed as family friendly by the employees at the department. This opens up the possibility for at least two different interpretations. (1) The work in the branches might be perceived as family friendly by the male but not by the female employees, as the demands on the men as caregivers are not as high as the ones the women experience - what the men experience as family friendly, therefore, might not be experienced as such by the women. (2) The work in the branches and in the department 
is not that different in terms of family friendliness, and the coupling of the document handling department and family friendliness should be understood more as a result of the numerical female dominance and general expectations concerning women's care obligations than as a result of flexible working hours - and vice versa with the work at the branches.

\section{Summary of low status and work-life balance}

The work in the document handling department is generally articulated as having low status in the organization. The low status is explicitly coupled to female gender. This, on the one hand, is done by naturalizing job preferences and behavior in relation to status as a matter of gender - women are said not to care about status and to more often prefer document handling than men. On the other hand, the numerical female dominance is also presented as a cause of low status. The latter of these 'explanations' may very well be understood as linked to the framing of the work in the department as family friendly and thereby feasible to do for employees (read: women) who are assumed to downgrade their work as they supposedly have more care obligations than men. The work in the document handling department is thus organized around a trade-off between status and (an image of) flexible working hours, which is expected to attract female employees.

\section{Conclusion and Discussion}

\section{Conclusion}

The gender switch in administrative work, which took place in the early 20th century, amply illustrates that changes in the articulation of gender and work can happen, and even relatively quickly. Nonetheless, we have since seen inertia in the linkage between the female gender and many types of administrative work, an inertia which often seems to turn this linkage into something almost inherently natural. On this basis, at the beginning of this article, we raised the question of why, even today, this gender segregation of labor in administrative work is often presented as almost inherently natural, even in the case of a newly established job type, like in the document handling department in the bank we examined.

On the basis of Acker's work, we raised the questions of whether or not the numerical female domination at the document handling department is an expression of a job function where women are seen as the ideal employee or if the domination is an expression of men's deselection more than women's choice.

We answered this by analyzing what notions about gender are being articulated and how they are linked to the work. Our conclusion is that we see a clear interplay between gender and work in the document handling department of the bank we examined. Document handling and female gender are interlinked as status, family flexibility, and the nature of the work and these categories overlap each other, supplement each other, and serve as each other's substitute. We can conclude that women, on the one side, are articulated as the ideal employee at the document handling department because of their particular female competences. On the other hand, these competences are linked to low pay, low status, and 
low prestige - a residual to jobs at the local branches. This double construction suggests that the linkage to gender will be hard to break.

We therefore claim that what is presented as inevitable requirements of the work in the document handling department and what is understood to be female competences produce and reproduce each other mutually through the construction of an ideal employee. Acker's thesis (1990) that the ideal employee is a man with no care obligations, with a life centered on full-time work is to a certain degree confirmed in our study. But our analysis also shows that the ideal employee can be a woman who, due to care obligations, wants to - and is content with - special working conditions and job content and who, moreover, may be ascribed special competences.

The document handling women themselves apply a double perspective when they explain female numerical domination. They look at their job both from within the department and from the outside. The female document handlers thereby also characterize themselves as simultaneously residual labor, as their job function is not wanted by men, and as in a function, where women are the ideal employee.

However, this does not change the fact that a notion like this, of an ideal employee of a certain gender, leads to great inertia, inertia both in the notions of the work and the requirements that can be demanded of employees, as well as in the notions of what gender is and how it is relevant in relation to work and other aspects of life.

\section{Discussion}

The historical perspective and the bank's organizational development sow doubt about the importance of whether the job type is new or not, formally speaking. The formal division between advice/sales and document handling has happened within the last 10 years in the bank and is as such relatively new. However, the division can be associated with the historically conditioned female dominance, and not least the historically conditioned notions of special female competences. Furthermore, there is the organizational context. Female-dominated support functions for advisers/salespersons existed before the establishment of the document handling department. These two circumstances together offer an explanation for how the division of the advice/sales function and the document handling function could take place, seemingly without anyone wondering why almost only women went over to the document handling function. It is a segregation of labor which indicates that organizational change does not necessarily break with existing gender structures but, on the contrary, can enhance them, unless there is a conscious focus on gender equality throughout the entire process. Gender as a concept may very well be "as wet soap in slippy hands" 17 (Simonsen, 1996); however, as an imagined connection between the image of the ideal employee and a job type, gender is as sticky as an old piece of toffee in a trouser pocket.

But there are also elements of change, e.g., in the displacement toward competence-oriented rather than more passive female characteristics, albeit these still play a role. This provides the basis for a professional pride as well as anger about the failure to appreciate competences. At the same time, inertia and change provide the basis for potential conflict in the organization and production of research: Is it possible, on the one hand, to maintain a focus on the possibilities for change (and on the fact that biological gender is not what defines social gender) and, on the other hand, focus on 
the inertia in the social processes, which shows that change rarely just happens on its own?

However, our focus on the construction and discussion of the ideal employee does not merely highlight the historical inertia of the gender stereotypes in our research material, it also makes the resistance to parts of this construction and thereby potentials for change visible. Because the interviews in the document handling department also give the impression that at least some of the employees relate to the fact that they, and their function, are constructed in a certain manner by their surroundings in the bank. They express frustration or anger that their competences are not being appreciated, and they indicate that gender plays a role for how the surroundings view their work. That these women relate to the construction of themselves and their function, and thus potentially to the arbitrariness of these constructions, could form the basis for problematizing their validity and thus sowing the seeds of change. However, without intensive efforts, it is still difficult to imagine that any real changes will be made to the construction of document handling as women's work, considering the strong double construction of the job function as simultaneously representing residual labor and ideal, feminized, competences.

\section{References}

Aaltio-Marjosola, L. (1994). Gender Stereotypes as Cultural Products of the Organization. Scandinavian Journal of Management, vol. 10, Issue 2, pp. 147-162. Elsevier Publishing.

Acker, J. (1990). Hierarchies, Jobs, Bodies: A Theory of Gendered Organizations. Gender \& Society, vol. 4, Issue 2, pp. 139-158. Sage Publishing.

Acker, J. (1994/2006). The Gender Regimes of Swedish Banks. Scandinavian Journal of Management, vol. 10, Issue 2, pp. 117-130. Elsevier Publishing.

Acker, J. (2006a). Inequality Regimes: Gender, Class, and Race in Organizations. Gender \& Society, vol. 20, Issue 4, pp. 441-464. Sage Publishing.

Acker, J. (2006b). Comments on: “The Gender Regimes of Swedish Banks”. Scandinavian Journal of Management, vol. 22, Issue 3, pp. 210-212. Elsevier Publishing.

Andersen, N. Å. (1999). Diskursive analysestrategier. Foucault, Koselleck, Laclau, Luhmann [Discursive analytical strategies. Foucault, Koselleck, Laclau, Luhmann]. Copenhagen: Nyt fra Samfundsvidenskaberne.

Bailyn, L. (2006). Breaking the Mold. Ithaca, NY: Cornell University Press (2nd edition).

Bloksgaard, L. (2008). Kompetencekrav, Familiepolitikker og køn i moderne Arbejdspladskontekster [Competence requirements, Family policies and Gender in modern workplace contexts]. In R. Emerek \& H. Holt (Eds.). Lige muligheder - Frie valg? [Equal Possibilities - Free Choices?] Copenhagen: SFI - The Danish National Centre for Social Research, 08, 24, pp. 317-341.

Boyer, K. (2004). "Miss Remington" Goes to Work: Gender, Space and Technology at the Dawn of the Information Age". The Professional Geographer, vol. 56, Issue 2, pp. 201-212. Oxford: Blackwell Publishing.

Britton, M. D. (1997). Gendered Organizational Logic. Policy and Practice in Men's and Women's Prisons. Gender \& Society, vol. 11, Issue 6, pp. 796-818.

Danish Ministry of Employment (2002). Kønsarbejdsdeling og arbejdsmarkedet [Gender segregation and the labour market]. Copenhagen.

Deding, M. (2010). Kønsarbejdsdeling i familien og ligeløn [The segregation of labour in the family and equal pay] In M. Deding \& H. Holt (Eds.). Hvorfor har vi lønforskelle mellem kvinder og moend? - En antologi om ligeløn i Danmark [Why Do we Have Unequal Pay 
between Women and Men? - An Anthology about Equal Pay in Denmark]. København: SFI - Det Nationale forskningscenter for velfærd: 10:12, pp. 99-117.

Deding, M. \& Laustsen, M. (2008). Kønsarbejdsdeling i familien og på arbejdsmarkedet. En analyse blandt beskæftigede mødre og fædre [The segregation of labour in families and at the labour market] In R. Emerek \& H. Holt (Eds.). Lige muligheder - Frie valg? [Equal Possibilities - Free Choices?] Copenhagen: SFI - The Danish National Centre for Social Research, 08:24, pp. 293-317.

Due Billing, Y. (2005). Ledere under forandring? [Management Changing?] København: Jurist- og Økonomforbundets Forlag.

Ellehave, C. F. \& Søndergaard, D. M. (2006). Køn i den Finansielle Sektor [Gender in the financial sector]. VIFA, 2nd sub report. The Danish School of Education.

Eriksson-Zetterquist, U. (2008). Gendered role modelling - a paradoxical construction process. Scandinavian Journal of Management, vol. 24, Issue 3, pp. 259-270. Elsevier Publishing.

Financial Services' Union. (2006). Særkørsel fra undersøgelsen Smil, du er på [A special run from the investigation: Smile you are on]. Copenhagen.

Foucault, M. (1986). The Archaeology of Knowledge. London: Tavistock Publications.

Geertsen, K. (1990) Dannet ung pige søges [Cultured young woman wanted]. Akademisk Forlag. Copenhagen.

Grosen, S. L. (2009). IT, arbejde og køn i anvendelse - samproduktion i det kvindedominerede administrative arbejde [IT, work and gender in practise - a coproduction in the female dominated administrative work]. PhD dissertation, Department of Environmental, Social and Spatial Change, Roskilde, Roskilde University.

Grosen, S. L., Holt, H., Hvid, H. \& Lund, H. (2010). 'Jeg bliver sådan helt nervøs, hvis det var en mand, der skulle lave det'. Naturliggørelse af kønsarbejdsdelingen i en bankafdeling ["I get all nervous if a man was supposed to handle it". Naturalization of the gender segregation in a bank department]. Tidsskrift for arbejdsliv, vol. 12, Issue 2, pp. 71-87. København: WERKS Grafiske hus.

Grugulis, I. \& Vincent, S. (2009). Whose skill is it anyway? 'Soft' skills and polarization. Work, Employment \& Society, vol. 23, Issue 4, pp. 597-615, Sage Publications.

Hasle, P., Hvid, H., Kristensen T. S., Limborg, H. J., Møller, N., Pejtersen, J. \& Hvenegaard, H. (2008). Virksombeders indsats for et bedre psykisk arbejdsmiljø [Business' effort to make a better psycho social working environment]. Copenhagen: Danish Working Environment Research Fund.

Holt, H., Hvid, H., Grosen, S. L. \& Lund, H. L. (2009). IT, køn og psykisk arbejdsmiljø i administrativt arbejde [IT, gender and psycho social working environment in administrative work]. København: SFI - The Danish National Centre for Social Research.

Holt, H. \& Lewis, S. (2011). 'You Can Stand on Your Head and Still End Up with Lower Pay': Gliding segregation and gendered work practices in Danish family-friendly workplaces. Gender, Work and Organization. Online published. www.Wiley.com. Blackwell Publishing Ltd.

Højgaard, L. (1993). De uadskillelige - om arbejde og familieliv [Work and family - life's inseparable pair]. In S. Carlsen \& J.E. Larsen (Eds.). Den sveere balance [The Equality Dilemma]. Copenhagen: Ligestillingsrådet (Danish Equal Status Council), pp. 15-29.

Juul, I. (2008). Kontorarbejdets udvikling fra mandefag til kvindefag [The development of administrative work from a male to a female dominated profession]. Cursiv, vol. 3, pp. 77-100. København: DPU.

Martin, P. Y. (2003). "Said and done" versus "saying and doing” gendering practices, practicing gender at work. Gender and Society, vol. 17, Issue 3, pp. 342-366. Sage Publishing.

Martin, P. Y. (2006). Practising gender at work: further thoughts on reflexivity. Gender, Work \& Organization, vol. 13, Issue 3, pp. 254-276. Blackwell Publishing Ltd. 
Moss Kanter, R. (1977). Men and Women of the Corporation. New York: Basic Books, Inc.

Perrons, D. (2003). The new economy and the work-life balance: conceptual explorations and a case study of new media. Gender, Work and Organization, vol. 10, Issue 1, pp. 65-93. Blackwell Publishing.

Rees, B. \& Garnsey, E. (2003). Analysing competence: gender and identity at work. Gender, Work and Organization, vol. 10, Issue 5, pp. 551-578. Oxford: Blackwell Publishing.

Simonsen, D. G. (1996). Som et stykke vådt sæbe mellem fedtede fingre. Køn og poststrukturalistiske strategier [As wet soap in slippery hands. Gender and post structuralistic strategies]. Kvinder, Køn \& Forskning, vol. 2, pp. 29-50. København: Københavns Universitet.

Smistrup, M. (2003). Bankmedarbejderen: splittet mellem Varnoes og Scrooge (og Merkur venter $i$ kulissen): fag, faglighed og identitet blandt danske bankmedarbejdere [The bank employee: split between Varnos and Scrooge (and Merkur is waiting in the wings: profession, professionalism and identity among Danish bank employees]. $\mathrm{PhD}$ dissertation, Roskilde: Roskilde University (http://hdl.handle.net/1800/572).

Smithson, J., Lewis, S., Cooper, C. \& Dyer, J. (2004). Flexible working and the gender pay gap in the accountancy profession. Work, Employment \& Society, vol. 18, Issue 1, pp. 115-135. BSA Publications Ltd.

Swanberg, J. J. (2004). Illuminating gendered organization assumptions. An important step in creating a family-friendly organization: a case study. Community, Work and Family, vol. 1, Issue 1, pp. 3-28. Carfax Publishing Ltd.

Tienari, J. (2000). Gender segregation in the making of a merger. Scandinavian Journal of Management, vol.16, Issue 2, pp. 111-144. Elsevier Publishing.

\section{End note}

${ }^{1}$ This chapter springs from the research project Kontrolformer, køn og psykisk arbejdsmiljø i IT baseret adminstrativt arbejde (Forms of control, gender and psycho-social working environment in IT-based administrative work), funded by the Danish Working Environment Research Fund.

${ }^{2}$ Authors' translation

${ }^{3}$ It is beyond the scope of this chapter to discuss an actual discourse analysis or the conceptual framework for such an analysis. We refer instead to Foucault's The Archaeology of Knowledge (1986) and discussions on the conceptual framework in Andersen (1999) and Grosen (2009).

${ }^{4}$ Authors' translation.

${ }^{5}$ Authors' translation.

${ }^{6}$ Authors' translation.

${ }^{7}$ Authors' translation.

${ }^{8}$ Authors' translation.

${ }_{9}^{9}$ Authors' translation.

${ }^{10}$ Authors' translation.

${ }^{11}$ Authors' translation.

${ }^{12}$ Other studies, however, have shown that centralization of document handling is a common phenomenon in most Danish banks (see, e.g., Peter Hasle et al., 2008).

${ }_{13}$ Authors' translation.

${ }^{14}$ Authors' translation.

${ }^{15}$ Authors' translation.

${ }^{16}$ Authors' translation.

${ }^{17}$ Authors' translation. 